\title{
Diagnostic performance of EBUS-TBNA and its interrelation with PET-CT in patients with extra-thoracic malignancies
}

\author{
Ezgi DEMIRDÖĞEN ${ }^{1}($ ID) \\ Ahmet URSAVAŞ ${ }^{1}$ (ID) \\ Özge AYDIN \\ GÜÇLÜ²(ID) \\ Nilüfer Aylin \\ ACET ÖZTÜRK ${ }^{\mathbf{1}}$ (ID) \\ Güven ÖZKAYA ${ }^{3}$ (ID) \\ Mehmet KARADAĞ ${ }^{1}$ (ID)
}

${ }^{1}$ Department of Chest Diseases, Faculty of Medicine, Uludag University, Bursa, Turkey

${ }^{1}$ Uludağ Üniversitesi Tıp Fakültesi, Göğüs Hastalıkları Anabilim Dalı, Bursa, Türkiye

${ }^{2}$ Clinic of Chest Diseases, Boyabat $75^{\text {th }}$ Year State Hospital, Sinop, Turkey

${ }^{2}$ Boyabat 75. Yıl Devlet Hastanesi, Göğüs Hastalıkları Kliniği, Sinop, Türkiye

${ }^{3}$ Department of Biostatistics, Faculty of Medicine, Uludag University, Bursa, Turkey

${ }^{3}$ Uludağ Üniversitesi Tıp Fakültesi, Biyoistatistik Anabilim Dalı, Bursa, Türkiye

* Presented at TRS Annual Congress 2019 in Bodrum, Turkey.

Cite this article as: Demirdöğen E, Ursavas A, Aydın Güçlü Ö, Acet Öztürk NA, Özkaya G, Karadağ M. Diagnostic performance of EBUS-TBNA and its Interrelation with PET-CT in patients with extra-thoracic malignancies. Tuberk Toraks 2020;68(3):285-292.

\section{Yazışma Adresi (Address for Correspondence)}

\section{Dr. Ezgi DEMIRDÖĞEN}

Uludağ Üniversitesi Tıp Fakültesi,

Gögüs Hastalıkları Anabilim Dalı,

BURSA - TÜRKIYE

e-mail: demirdogenezgi@gmail.com

CCopyright 2020 by Tuberculosis and Thorax.

Available on-line at www.tuberktoraks.org.com

\begin{abstract}
Diagnostic performance of EBUS-TBNA and its interrelation with PET-CT in patients with extra-thoracic malignancies

Introduction: Endobronchial ultrasound-guided transbronchial needle aspiration (EBUS-TBNA) is a well-established diagnostic tool for lung cancer, sarcoidosis, and suspected metastatic extra-thoracic malignancy (ETM). Patients with primary ETM often have hypermetabolic mediastinal/hilar lymph node enlargement in the PET-scan done for initial staging or post treatment followup. We aimed to determine the diagnostic performance of EBUS-TBNA and the relationship between PET-SUV values and diagnosis of malignancy metastasis in patients with ETM.
\end{abstract}

Materials and Methods: Results of EBUS-TBNA in ETM patients with suspected MLN metastasis were retrospectively analysed (May 2016 to July 2019). Non-malign results were confirmed for surgery or clinical/radiological followup. Lymph nodes with a high FDG-uptake (SUV > 2.5, MLN) were reported as suspicious for metastasis.

Results: Of the 588 EBUS procedures, 109 were included in the analysis. Patient' mean age was $62.5 \pm 10.1$ years; there were 35 men and 74 women. Primary malignancies were breast cancer in 33, gastrointestinal in 23, female 
genital tract in 17, head and neck in 14, genitourinary cancer in 13, malignant melanoma in 6, sarcoma in 2 and kaposi sarcoma in 1. According to EBUS-TBNA smear and cell block histopathologic evaluations, 16 patients' results (14.7\%) were malignant compatible with metastasis of ETM. Among the 93 patients with non-malignant diagnosis, EBUS-TBNA revealed a granulomatous lympadenitis compatible with sarcoid reaction in 7 and tuberculosis in 2. A total of 9 patients underwent surgical procedures after EBUSTBNA, with a definitive histological diagnosis of granulomatous lymphadenitis in 2, malignancy in 5 and, reactive lymph node in 2. Overall sensitivity, specificity, positive predictive value, negative predictive value and diagnostic accuracy of EBUS-TBNA were 76.19\% (95\% Cl 52.83-91.78), 100\% (95\% Cl 95.89-100.00), 100\%, 94.62\% (95\% Cl 89.12-97.12) and 95.4\%, respectively.

Conclusion: EBUS-TBNA sampling has high diagnostic performance. Histopathological confirmation requirement for MLN should be kept in mind in patients with ETM, even they have negative EBUS results.

Key words: Endobrochial ultrasound; transbronchial needle aspiration; extra-thoracic malignancy; PET-CT; diagnostic performance

\section{Öz}

\section{Ekstra-torasik maligniteli hastalarda EBUS-TBiA tanı değeri ve PET-BT ile ilişkisi}

Giriş: Endobronşial ultrason-kılavuzluğunda transbronşial iğne aspirasyonu (EBUS-TBiA), akciğer kanseri, sarkoidoz ve metastatik ekstra-torasik malignitelerde (ETM) iyi tanımlanmış bir tanı yöntemidir. Primer ETM evrelemesi ve tedavi sonrası takipte, mediastinal/ hiler lenf nodu (MLN) genişlemesi sık görülmektedir. ETM tanısı olan hastalarda EBUS-TBiA tanı performansı, PET-SUV değerleri ile malign metastaz tanısı arasındaki ilişkiyi araştırmayı hedefledik.

Materyal ve Metod: Şüpheli malign metastaz olan ETM hastalarında yapılan EBUS-TBIA sonuçları retrospektif olarak analiz edildi (Mayıs 2016-Temmuz 2019). Malign olmayan sonuçlar cerrahi veya klinik/radyolojik takip ile konfirme edildi. Yüksek FDG-uptake olan (SUV > 2.5, MLN) lenf nodları metastaz şüpheli olarak raporlandı.

Bulgular: Toplam 588 EBUS işleminden 109'u analize dahil edildi. Hastaların ortalama yaşı 62.5 \pm 10.1 ; 35'i erkek, 74'ü kadın idi. Primer malignitelerin, 33'ü meme kanseri, 23'ü gastrointestinal, 17'si kadın genital sistem, 14'ü baş-boyun, 13'ü genitoüriner kanser, 6'sı malign melanom, 2'si sarkom ve 1'i kaposi sarkomu idi. EBUS-TBiA yayma ve hücre bloğu histopatolojik sonuçlarına göre 16 hastada (\%14.7) ETM metastazı ile uyumlu malignite saptandı. Malign olmayan 93 hastadan 7'sinde sarkoid reaksiyon ile uyumlu granülomatöz lenfadenit, 2'sinde tüberküloz, 5'inde malignite bulundu. EBUS-TBiA sonrası cerrahi ile toplam 9 hastanın 2'sinde granülomatöz lenfadenit, 5 'inde malignite ve 2'sinde reaktif lenf nodu saptandı. EBUS-TBiA için toplam duyarlıık, özgüllük, pozitif prediktif değer, negatif prediktif değer ve tanı doğruluğu, sırasılla \%76.19 (\%95 GA 52.83-91.78), \%100 (\%95 GA 95.89-100.00), \% 100, \%94.62 (\%95 GA 89.12-97.12) ve \%95.4 olarak saptandı.

Sonuç: EBUS-TBIA örneklemesi tanı performansı yüksek bir yöntemdir. Negatif EBUS sonuçları olsa da, MLN genişlemesi olan ETM tanılı olgularda histopatolojik doğrulama gerekliliği akılda tutulmalıdır.

Anahtar kelimeler: Endobronşial ultrason; transbronşiyal iğne aspirasyonu; ekstra-torasik malignensi; PET-BT; tanı performansı

\section{INTRODUCTION}

Endobronchial ultrasound-guided transbronchial needle aspiration (EBUS-TBNA) is a well-established diagnostic tool for lung cancer, sarcoidosis, and suspected metastatic extra-thoracic malignancy (ETM). The most common solid tumours include breast, head and neck, colorectal, genitourinary, oesophagus, melanoma and sarcoma (1-5). Mediastinal/hilar lymph node (MLN) enlargement is common in follow-up patients with previously treated malignancies.

Positron emission tomography with 18-fluorodeoxyglucose (PET)- computed tomography (CT), as a non-invasive method, has high sensitivity in the determination of MLNs. The approach to PET-positive MLN in the initial diagnosis or follow-up of cancer post treatment presents certain challenges. In practice, while a low SUV (standardized uptake values) needs tissue confirmation, a high SUV is highly suggestive of malignancy. In general, an SUV exceeding 2.5 in the MLN is considered highly suggestive of an active process, which has to be clinically correlated to define the risk of malignancy (6). However, due to high rates of false positivities, especially when granulomatous and inflammatory diseases are involved, histological verification is often required with more invasive procedures, such as mediastinoscopy or video-assisted thoracoscopic surgery (VATS) (7). EBUS-TBNA presents a minimally invasive alternative to mediastinoscopy. This procedure has few associated complications, is cost effective, and provides access to the hilar, interlobar and subcarinal lymph nodes (8). Additionally, it has much higher sensitivity and specificity than conventional TBNA for the assessment of mediastinal and hilar lymph nodes (9).

We aimed to determine the diagnostic performance of EBUS-TBNA and the relationship between PET-SUV 
values and diagnosis of MLNs metastasis with EBUSTBNA in patients with ETM.

\section{MATERIALS and METHODS}

All EBUS-TBNA cases performed from May 2016 to July 2019 were retrospectively reviewed. Results of EBUS-TBNA in ETM patients with suspected hilar and/ or mediastinal metastasis were analyzed. Patients diagnosed with benign reactive adenopathy by EBUSTBNA subsequently underwent surgery or clinical/ radiological follow-up. Clinical and radiological follow-up period was noted according to patient' medical records.

Before the procedure, all patients underwent detailed clinical evaluation, laboratory tests (complete blood count, liver and kidney function tests), chest radiograph and PET-CT scan. PET-CT imaging was performed using a Biograph 6 LSO scanner (Siemens Mediacal Systems, Erlangen, Germany). SUV values were calculated using body weight and pathologic metabolic activity foci were evaluated visually and quantitatively. Lymph nodes with high FDG uptake (SUV > 2.5, MLNs) were reported as suspicious for metastasis.

The MLNs were sampled with a convex probe EBUS (7.5 MHz, BFUC180F; Olympus, Tokyo, Japan), guided TBNA from various mediastinal and hilar locations under conscious sedation, using midazolam, propofol and remifentanil. Using "spray as you go" method, topical anaesthesia was applied with 10\% lidocaine spray to the vocal cords and $2 \%$ lidocaine to the airways (maximum $8 \mathrm{mg} / \mathrm{kg}$ ). All EBUS procedures were performed on patients by two experienced pulmonologists. All EBUS accessible lymph nodes were sampled, regardless of FDG avidity. At least 3 real-time guided punctures were made in each MLN, with a 22-gauge EBUS needle (NA-201SX-4022; Olympus, Tokyo, Japan). Samples were simultaneously expressed onto glass slides, smeared and air-dried for cytology, and expelled into liquid fixatives (mixture of formaldehyde and alcohol) for cell block processing and histological evaluation. Air dried smears were stained with a May-Grunwald Giemsa stain. All materials were evaluated by the same experienced cytopathologist. EBUS-TBNA samples were also sprayed with $0.9 \%$ $\mathrm{NaCl}$ from each patient and sent to the microbiology laboratory, for acid-resistant bacillus (ARB) microscopic examination and mycobacterium culture. Presence of mature and transformed lymphocytes, with or without a conclusive diagnosis, was defined 'adequate sample'; while absence of lymphocytes or presence of scant cellularity, only blood or benign bronchial cells was defined 'inadequate sample' (10).

\section{Statistical Analysis}

Statistical analyses were performed with IBM SPSS ver.23.0 (IBM Corp. Released 2015. IBM SPSS Statistics for Windows, Version 23.0. Armonk, NY: IBM Corp.). The results were presented as mean \pmstandard deviation for continuous variables and as frequency and percentage for categorical variables. Diagnostic accuracies of PET-CT were compared with chi-square test. Diagnostic sensitivity, specificity, positive predictive value (PPV), negative predictive value (NPV) and accuracy were calculated using standard definitions. A p-value $<0.05$ was considered as statistically significant.

\section{RESULTS}

Of the 588 EBUS procedures, 109 were included in the analysis. Patients' mean age was $62.5 \pm 10.1$ years; 35 (32\%) were men and 74 (68\%) women. Primary malignancies were breast cancer in $33(30.3 \%)$, gastrointestinal in $23(21.1 \%)$, female genital tract in $17(15.6 \%)$, head and neck in $14(12.9 \%)$, genitourinary in 13 $(12 \%)$, malignant melanoma in $6(5.5 \%)$, sarcoma in 2 $(1.8 \%)$ and Kaposi sarcoma in $1(0.9 \%)$ (Figure 1$)$. Median size of lymph nodes seen at EBUS-TBNA was $8.40 \mathrm{~mm}(2.80-23.40)$ for the short axis and $12.60 \mathrm{~mm}$ (4.30-31.40) for the long axis, with each node having undergone a median of 3 passes (range 1-6). Overall, 406 lymph nodes were sampled at 10 different stations from 109 patients (Table 1). All samples were adequate. Median length of time from ETM diagnosis to EBUSTBNA procedure was 2 (0-18) years. According to EBUS-TBNA smear and cell block histopathologic evaluations, 16 patients' results $(14.7 \%)$ were malignant compatible with metastasis of extrapulmonary cancer. Median follow-up duration was 6 (3-36) months in patients with benign EBUS-TBNA results. Among the 93 patients with non-malignant diagnosis, EBUS-TBNA revealed granulomatous lymphadenitis compatible with sarcoid reaction in $7(6.4 \%)$, tuberculosis in 2 $(1.8 \%)$ (culture positivity in addition to granulomatous lymphadenitis). Reactive lymph node was found in 84 $(77.1 \%)$ of 93 patients with EBUS-TBNA. Among the patients who had reactive lymph node EBUS-TBNA results, a total of 9 patients underwent surgical procedures, (mediastinoscopy, mediastinotomy, VATS) with a definitive histological diagnosis of granulomatous lymphadenitis in 2 patients, metastasis of ETM in 5 


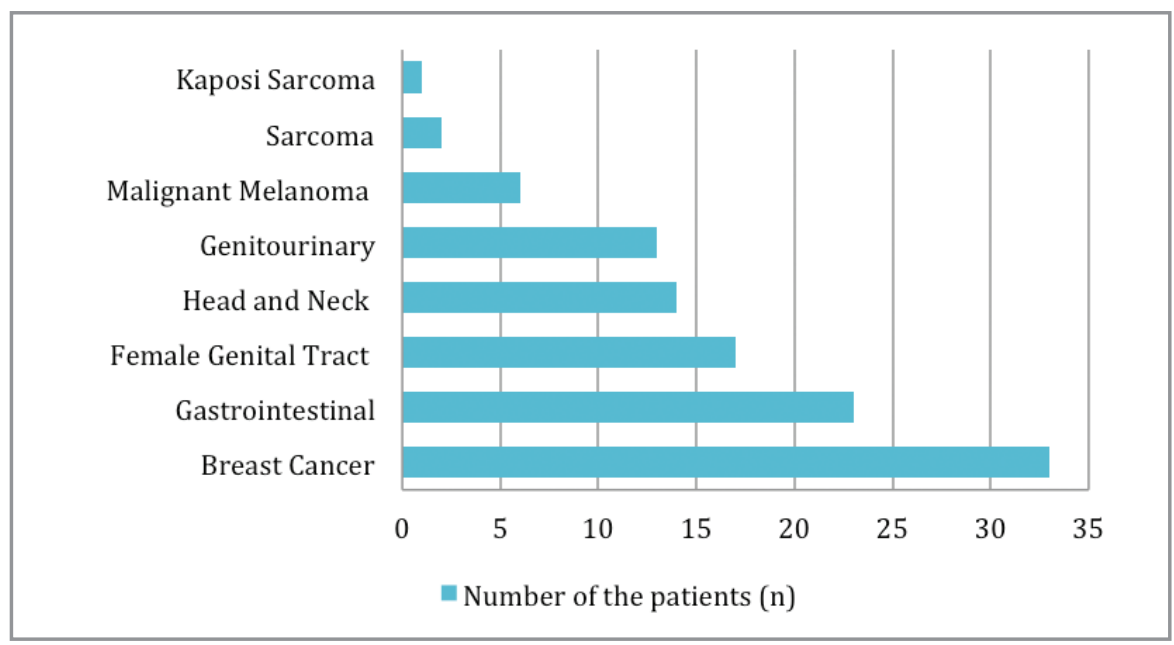

Figure 1. Distribution of primary malignancies.

\section{Table 1. Distribution of sampled lymph nodes locations}

\begin{tabular}{|lccccc|}
\hline Lymph nodes & $\mathbf{N}$ & $\mathbf{\%}$ & Lymph node passes & Lymph node short axis & Lymph node long axis \\
\hline 7 & 105 & 96.3 & $3.26 \pm 0.52$ & $11.95 \pm 3.92$ & $17.90 \pm 5.48$ \\
$4 \mathrm{R}$ & 73 & 67 & $3.19 \pm 0.68$ & $8.51 \pm 3.35$ & $14.12 \pm 3.72$ \\
$4 \mathrm{~L}$ & 37 & 33.9 & $3.16 \pm 0.55$ & $7.14 \pm 3.99$ & $10.25 \pm 4.57$ \\
$11 \mathrm{R}$ & 71 & 65.1 & $2.91 \pm 0.52$ & $8.89 \pm 2.77$ & $12.30 \pm 3.66$ \\
$11 \mathrm{~L}$ & 71 & 65.1 & $3.02 \pm 0.33$ & $8.63 \pm 2.50$ & $13.40 \pm 3.27$ \\
$10 \mathrm{R}$ & 35 & 32.1 & $2.97 \pm 0.74$ & $9.00 \pm 3.50$ & $12.10 \pm 4.12$ \\
$10 \mathrm{~L}$ & 6 & 5.5 & $3.00 \pm 0.63$ & $11.82 \pm 5.06$ & $18.00 \pm 6.66$ \\
$2 \mathrm{R}$ & 5 & 4.6 & $3.40 \pm 1.81$ & $5.80 \pm 1.13$ & $9.95 \pm 7.00$ \\
$2 \mathrm{~L}$ & 2 & 1.8 & $4.00 \pm 1.41$ & $12.20 \pm 1.64$ & $18.66 \pm 2.07$ \\
$12 \mathrm{~L}$ & 1 & 0.9 & 3 & 8.50 & 11.80 \\
\hline
\end{tabular}

Table 2. The relationship between PET-CT (according to the cut-off SUVmax value of 2.5) and malign positive EBUS pathology results

\begin{tabular}{|lccccccccc|}
\hline Pathology & $\mathbf{7}$ & $\mathbf{4 R}$ & $\mathbf{4 L}$ & $\mathbf{1 1 R}$ & $\mathbf{1 1 L}$ & $\mathbf{1 0 R}$ & $\mathbf{1 0 L}$ & $\mathbf{2 R}$ & $\mathbf{2 L}$ \\
\hline SUVmax $\geq 2.5$ & $5(6.5 \%)$ & $5(9.1 \%)$ & $2(20 \%)$ & $5(12.8 \%)$ & $2(6.1 \%)$ & $3(11.5 \%)$ & $2(50 \%)$ & 0 & $1(100 \%)$ \\
SUVmax $<2.5$ & $3(15.8 \%)$ & $1(7.7 \%)$ & $1(4.2 \%)$ & 0 & 0 & $1(11.1 \%)$ & 0 & 0 & 0 \\
\hline
\end{tabular}

patients and, reactive lymph node in 2 . The interrelation of PET-CT (according to the cut-off SUVmax value of 2.5) and positive EBUS-TBNA pathology results of lymph nodes are shown in Table 2. Overall sensitivity, specificity, positive predictive value (PPV), negative predictive value (NPV) and diagnostic accuracy of EBUS-TBNA were $76.19 \%(95 \% \mathrm{Cl} 52.83-91.78)$, $100 \%$ (95\% Cl 95.89-100.00), 100\%, 94.62\% (95\% Cl $89.12-97.12$ ) and $95.4 \%$, respectively (Table 3 ).

\section{DISCUSSION}

In this study, we aimed to evaluate the diagnostic performance of EBUS-TBNA, and the relationship between PET-SUV values and diagnosis of malignancy in patients with ETM. We determined overall sensitivity, specificity, PPV, NPV and diagnostic accuracy of EBUS-TBNA to be $76.19 \%, 100 \%, 100 \%, 94.62 \%$ and $95.4 \%$, respectively. 
Table 3. EBUS-TBNA malign diagnostic performance

\begin{tabular}{|c|c|c|c|}
\hline \multicolumn{4}{|c|}{ Final diagnosis } \\
\hline & Negative & Positive & Total \\
\hline EBUS negative & 88 & 5 & 93 \\
\hline EBUS positive & 0 & 16 & 16 \\
\hline Total & 88 & 21 & 109 \\
\hline $\begin{array}{l}\text { Sensitivity }=16 / 21=76.19 \% \\
\text { Spesificity }=88 / 88=100 \%(9 \\
\text { Negative predictive value }=8 \\
\text { Positive predictive value }=16 \\
\text { Accuracy }=104 / 109=95.4 \%\end{array}$ & Cl 89.12-97. & & \\
\hline
\end{tabular}

Many recent articles have demonstrated the effectiveness and safety of EBUS-TBNA in different oncological settings $(11,12)$. Being minimally invasive, the procedure has become the preferred approach for mediastinal staging in lung cancer, for tissue sampling of mediastinal and lung tumours, as well as for diagnosis of inflammatory and lymphoproliferative disorders $(13,14)$. Yasufuku et al. reported EBUS-TBNA to have $94.6 \%$ sensitivity, $100 \%$ specificity and $89.5 \%$ NPV in lung cancer, with its accuracy being $96.3 \%$ (15). In comparison to mediastinoscopy, EBUS-TBNA and PET/ CT have higher sensitivity, specificity and NPV in mediastinal staging (16). In cases that require further investigation, EBUS-TBNA, which allows easy "redo" sampling, proves also to be more advantageous than mediastinoscopy, in which repeat sampling is more difficult and less safe. Distribution of ETM in our study was breast cancer in $33(30.3 \%)$, female genital tract in $17(15.6 \%)$, head and neck in $14(12.9 \%)$, gastrointes- tinal in $23(21.1 \%)$, genitourinary in $13(12 \%)$, malignant melanoma in $6(5.5 \%)$, sarcoma in $2(1.8 \%)$ and Kaposi's sarcoma in $1(0.9 \%)$ patients. Reference standart was radiological/clinical follow up or surgery as in previous studies (3-5,17-23). Tournoy et al analysed 92 patients with ETM with suspicion of mediastinal or hilar spread, who underwent EBUS-TBNA for diagnosis (4). Majority of the study population (nearly $70 \%$ ) had head and neck carcinoma, colorectal carcinoma, and renal cell carcinoma. Twenty-nine cases (31.5\%) were identified with benign conditions, such as reactive adenopathy, sarcoidosis, silicosis, and hamartoma, as a final diagnosis. Nine patients had surgical biopsies that showed metastatic disease. The sensitivity and NPV of EBUS-TBNA in detecting mediastinal spread of ETM were reported as $85 \%$ and $76 \%$, respectively (4). Other studies also showed sensitivity rate of 78.2$95.7 \%$ (Table 4). In the present study, the sensitivity of EBUS-TBNA in ETM patients with suspicion of medias-

Table 4. Summary of the literature for EBUS-TBNA diagnostic performance in ETM patients with mediastinal/hilar lymph node

\begin{tabular}{|c|c|c|c|c|c|}
\hline Study & No of patients & $\begin{array}{l}\text { Sensitivity } \\
(\%)\end{array}$ & $\begin{array}{l}\text { Specificity } \\
(\%)\end{array}$ & $\begin{array}{l}\text { NPV } \\
(\%)\end{array}$ & $\begin{array}{c}\text { Diagnostic accuracy } \\
(\%)\end{array}$ \\
\hline Navani et al., 2011/consecutive cases (3) & 161 & 87 & - & 73 & 88 \\
\hline Tournoy et al., 2011/consecutive cases (4) & 92 & 85 & - & 76 & - \\
\hline Song et al., 2011/consecutive cases (17) & 57 & 88 & - & 85 & 93 \\
\hline Park et al., 2011/retrospective (18) & 59 & 81 & 100 & - & - \\
\hline Parmaksız et al., 2012/ consecutive cases (20) & 48 & 89.2 & 100 & 86.9 & 93.7 \\
\hline Özgül et al., 2013/retrospective (19) & 40 & 90 & 100 & 90.9 & 95 \\
\hline Sanz-Santos et al., 2013/retrospective (5) & 117 & 86.4 & - & 75 & 90.3 \\
\hline Şentürk et al., 2014/consecutive cases (22) & 54 & 93 & 100 & 92.6 & 96.3 \\
\hline Erer et al., 2016/retrospective (21) & 63 & 78.2 & 100 & 88.3 & 91.8 \\
\hline Tertemiz et al., 2017/retrospective (23) & 91 & 90.2 & 100 & 92.5 & 95.6 \\
\hline Guarize et al., 2017/retrospective (2) & 176 & 95.7 & 100 & 92.3 & 97.2 \\
\hline This study, 2019 & 109 & 76.19 & 100 & 94.6 & 95.4 \\
\hline
\end{tabular}


tinal metastasis was $76.19 \%$, which is similar in research of Erer et al (21). In a study by Song et al, of the 57 patients with proven or suspicious ETM, 35 $(61.4 \%)$ were confirmed to have malignancies, while EBUS-TBNA identified malignancy in 30 patients (17). In the same study, overall cancer prevalence was found to be $61 \%$, while diagnostic sensitivity, accuracy and NPV of EBUS-TBNA per patient were $88 \%, 93 \%$ and $85 \%$, respectively (17). In another study, EBUS-TBNA was performed in patients with known extrapulmonary malignancies or suspected MLNs metastasis from unknown origin, for diagnostic purposes and its sensitivity and specificity, were determined to be $81 \%$, $100 \%$ respectively (18). Approximately $30 \%$ of the cases with ETM can metastasize to the mediastinum, manifesting as MLNs (24). EBUS-TBNA is a safe, effective and accurate procedure for MLN sampling; however, negative findings may require mediastinoscopy for further investigation (25).

In our study, EBUS-TBNA smear and cell block histopathologic evaluations identified 16 patients (14.7\%) to be malignant compatible with metastasis of ETM. Among the 93 patients with non-malignant diagnosis, EBUS-TBNA revealed granulomatous lymphadenitis compatible with sarcoid reaction in 7 cases and tuberculosis in 2. A total of 9 patients underwent surgical procedures after EBUS-TBNA, with a definitive histological diagnosis of granulomatous lymphadenitis in 2 and malignancy in 5 patients. Mehta et al showed that EBUS-TBNA revealed malignancy in 20/65 cases $(30.76 \%)$, and benign diagnoses in $69 \%$ of the cases [(tuberculosis in 6/65 (9\%), sarcoidosis 24/65 (37\%) and reactive lymph nodes in 15/65 (23\%)] (1). In one study, EBUS-TBNA sampling in ETM has shown that even for FDG avid cases, granulomas seen on histology had a 100\% NPV (26). Granulomas seen on histology, in these cases, indicate a sarcoid-like inflammatory reaction or an undiagnosed pulmonary sarcoidosis. The association between granulomatous MLN inflammation and malignancy is described as a "sarcoid-like reaction". This is seen in malignancies such as lung cancer, cutaneous malignancies, testicular germ cell tumour, renal cell carcinoma, hepatocellular carcinoma and digestive tract cancer. Various hypotheses exist as to its cause, such as an immunological dysfunction related to cancer, or a side effect of cancer therapy. The phenomenon is also described in cancer patients treated with surgery alone, with an explanatory theory postulating that "antigenic shedding" from the tumour leads to granuloma formation (27-29). Lower NPVs have also been reported for EBUS-TBNA performed due to suspicion of mediastinal metastasis in ETM, underscoring the importance of further investigation $(3,5)$. Moreover, it should be kept in mind that PET-CT positivity of mediastinal lymph nodes is nonspecific and occurs in benign and malignant conditions with similar frequency (30).

There are some limitations to our study. The retrospective design indicates that only clinically selected patients for EBUS-TBNA were included. Though consecutive patients were included to minimize this bias, features of patients directly referred for mediastinoscopy, outside of the study, were not known. Negative EBUS-TBNA results were not confirmed by surgical procedure in all patients. The data confirm the need for a surgical invasive investigation when EBUS-TBNA reveals a non-neoplastic diagnosis in highly suspect cases, in this subset of patients.

\section{CONCLUSION}

EBUS-TBNA sampling has high diagnostic performance in suspicion of mediastinal metastasis in ETM patients. Although surgical histological confirmation is required in cases with a strong suspicion of metastasis, the safe and less invasive EBUS-TBNA should be used as an initial diagnostic tool in ETM patients. Surgical histopathological confirmation should be kept in mind in patients with ETM, even they have negative EBUS results.

\section{ACKNOWLEDGMENTS}

We would like to acknowledge all participants who contributed their data to this research. All authors approved the final version of the manuscript.

Ethics Committee Approval: The approval for this study was obtained from Bursa Uludag University Faculty of Medicine Ethics Committee. (Decision no: 2017-2/11 Date: 14.02.2017).

\section{CONFLICT of INTEREST}

There is no conflict of interest related to this study.

\section{AUTHORSHIP CONTRIBUTIONS}

Concept/Design: All of authors

Analysis/Interpretation: ED, GÖ, AU, ÖAG

Data Acquisition: ED, NAAÖ, ÖAG, AU, MK

Writting: ED, ÖAG

Critical Revision: ED

Final Approval: All of authors 


\section{REFERENCES}

1. Mehta RM, Biraris P, Patil S, Singla A, Kallur K, Gasparini S. Utility of EBUS-TBNA in PET positive mediastinal lymph nodes in subjects with extra-thoracic malignancy. PLoS One 2019; 14(3): e0213437.

2. Guarize J, Casiraghi M, Donghi S, Casadio C, Diotti C, Filippi N, et al. EBUS-TBNA in PET-positive lymphadenopathies in treated cancer patients. ERJ Open Res 2017; 3(4): 00009-2017.

3. Navani $N$, Nankivell $M$, Woolhouse I, Harrison $R N$, Munavvar M, Oltmanns $U$, et al. Endobronchial ultrasound-guided transbronchial needle aspiration for the diagnosis of intrathoracic lymphadenopathy in patients with extrathoracic malignancy: a multicentre study. J Thorac Oncol 2011; 6(9): 1505-9.

4. Tournoy KG, Govaerts E, Malfait T, Dooms C. Endobronchial ultrasound-guided transbronchial needle biopsy for M1 staging of extrathoracic malignancies. Ann Oncol 2011; 22(1) :127-31.

5. Sanz-Santos J, Cirauqui B, Sanchez E, Andreo F, Serra P, Monso $E$, et al. Endobronchial ultrasound-guided transbronchial needle aspiration in the diagnosis of intrathoracic lymph node metastases from extrathoracic malignancies. Clin Exp Metastasis 2013; 30(4): 521-8.

6. Lowe VI, Hoffman JM, DeLong DM, Patz EF, Coleman RE. Semiquantitative and visual analysis of FDG-PET images in pulmonary abnormalities. I Nucl Med 1994; 35(11): 1771-6.

7. Bakheet SM, Powe J. Benign causes of 18-FDG uptake on whole body imaging. Semin Nucl Med 1998; 28(4): 352-8.

8. Mehta HJ, Tanner NT, Silvestri G, Simkovich SM, Shamblin C, Shaftman SR, et al. Outcome of patients with negative and unsatisfactory cytologic specimens obtained by endobronchial ultrasound-guided transbronchial fine-needle aspiration of mediastinal lymph nodes. Cancer Cytopathol 2015; 123(2): 92-7.

9. Yan $J H$, Pan $L$, Chen XL, Chen JW, Yan $L M$, Liu B, et al. Endobronchial ultrasound versus conventional transbronchial needle aspiration in the diagnosis of mediastinal lymphadenopathy: a meta-analysis. Springerplus 2016; 5(1): 1716 .

10. Cameron SE, Andrade RS, Pambuccian SE. Endobronchial ultrasound-guided transbronchial needle aspiration cytology: a state of the art review. Cytopathology 2010; 21(1): 6-26.

11. Cömert SŞ, Çağlayan B, Fidan A, Salepçi B, Doğan C, Demirhan $R$, et al. A comparision of endobronchial ultrasound-guided transbronchial needle aspiration and integrated positron emission tomography-computed tomography in the diagnosis of malignant mediastinal/hilar lymph nodes. Turk J Thorac Cardiovasc Surg 2012; 20: 843-49.

12. Kandemir Z, Sentürk A, Ozdemir E, Yildirim N, Hasanoğ/u $H C$, Keskin $M$, et al. The evaluation of hypermetabolic mediastinal-hilar lymph nodes determined by PET/CT in pulmonary and extrapulmonary malignancies: correlation with EBUS-TBNA. Turk J Med Sci 2015; 45(6): 1234-42.
13. Kinsey CM, Arenberg DA. Endobronchial ultrasoundguided transbronchial needle aspiration for non-small cell lung cancer staging. Am J Respir Crit Care Med 2014; 189(6): 640-9.

14. Wahidi MM, Herth F, Yasufuku K, Shepherd RW, Yarmus L, Chawla $M$, et al. Technical aspects of endobronchial ultrasound-guided transbronchial needle aspiration: CHEST guideline and expert panel report. Chest 2016; 149(3): 816-35.

15. Yasufuku K, Chiyo M, Koh E, Moriya Y, lyoda A, Sekine Y, et al. Endobronchial ultrasound guided transbronchial needle aspiration for staging of lung cancer. Lung Cancer 2005; 50(3): 347-54.

16. Warren WA, Hagaman JT. Endobronchial ultrasoundguided transbronchial needle aspiration for mediastinal staging in a community medical center. Ann Am Thorac Soc 2016; 13(10): 1802-7.

17. Song JU, Park HY, Jeon K, Koh WJ, Suh GY, Chung MP, et al. The role of endobronchial ultrasound-guided transbronchial needle aspiration in the diagnosis of mediastinal and hilar lymph node metastases in patients with extrapulmonary malignancy. Intern Med 2011; 50(21): 2525-32.

18. Park J, Jang SJ, Park YS, Oh YM, Shim TS, Kim WS, et al. Endobronchial ultrasound-guided transbronchial needle biopsy for diagnosis of mediastinal lymphadenopathy in patients with extrathoracic malignancy. J Korean Med Sci 2011; 26(2): 274-8.

19. Özgül MA, Çetinkaya E, Tutar N, Özgül G, Onaran $H$, Bilaçeroğlu S. Endobronchial ultrasound-guided transbronchial needle aspiration for the diagnosis of Intrathoracic lymphadenopathy in patients with extrathoracic malignancy: a study in a tuberculosis-endemic country. J Cancer Res Ther 2013; 9(3): 416-21.

20. ParmaksIz ET, Caglayan B, Salepci B, Comert SS, Kiral N, Fidan $A$, et al. The utility of endobronchial ultrasoundguided transbronchial needle aspiration in mediastinal or hilar lymph node evaluation in extrathoracic malignancy: Benign or malignant? Ann Thorac Med 2012; 7(4): 210-4.

21. Erer OF, Anar C, Erol S, Özkan S. The utility of EBUS-TBNA in mediastinal or hilar lymph node evaluation in extrapulmonary malignany. Turk J Med Sci 2016; 46(1): 112-9.

22. Şentürk $A$, Kiliç $H$, Hezer $H$, Karaduman Yalçin $F$, Hasanoğlu HC. Endobronchial ultrasound-guided transbronchial needle biopsy for the diagnosis of mediastinal lymphadenopathy in patients with extrathoracic malignancies. Turk J Med Sci 2014; 44(6): 989-95.

23. Tertemiz KC, Alpaydin AO, Karacam V. The role of endobronchial ultrasonography for mediastinal lymphadenopathy in cases with extrathoracic malignancy. Surg Endosc 2017; 31(7): 2829-36.

24. Bono AV, Lovisolo JA. Renal cell carcinoma--diagnosis and treatment: state of the art. Eur Urol 1997; 31(Suppl 1): 47-55. 
25. Gu $P$, Zhao $Y-Z$, Jiang $L-Y$, Zhang $W$, Xin $Y$, Han $B H$. Endobronchial ultrasound-guided transbronchial needle aspiration for staging of lung cancer: a systematic review and meta-analysis. Eur J Cancer 2009; 45(8): 1389-96.

26. Bellinger CR, Sharma D, Ruiz J, Parks G, Dotson T, Haponik EF. Negative predictive value of granulomas on EBUS-TBNA in suspected extrathoracic malignancy. Lung 2016; 194(3): 387-91.

27. Brincker H. Sarcoid reactions in malignant tumours. Cancer Treat Rev 1986; 13(3): 147-56.

28. Yamasawa H, Ishii Y, Kitamura S. Concurrence of sarcoidosis and lung cancer. A report of four cases. Respiration 2000; 67(1): 90-3.
29. Parra ER, Canzian M, Saber AM, Coêlho RS, Rodrigues FG, Kairalla RA, et al. Pulmonary and mediastinal "sarcoidosis" following surgical resection of cancer. Pathol Res Pract 2004; 200(10): 701-5.

30. Gan Q, Stewart JM, Valik E, Eapen G, Caraway NP. Cytologic evaluation of positron emission tomographycomputed tomography-positive lymph nodes sampled by endobronchial ultrasound-guided transbronchial needle aspiration: experience at a large cancer center. Arch Pathol Lab Med 2019; 143(10): 1265-70. 